\title{
Hyperintense lesion along the pyramidal tract on DWI in hypoglycaemic hemiplegia
}

\author{
Kazuto Tsukita, Takashi Kageyama, Toshihiko Suenaga
}

Department of Neurology, Tenri Hospital, Tenri, Nara, Japan

\section{Correspondence to} Dr Kazuto Tsukita, kazusan@kuhp.kyoto-u.ac.jp

Accepted 24 March 2016

\section{DESCRIPTION}

An 85 -year-old man with type 2 diabetes mellitus presented to our emergency department with sudden right limb weakness and dysarthria $90 \mathrm{~min}$ after onset. He was alert when examined and had a blood pressure of $163 / 89 \mathrm{~mm} \mathrm{Hg}$. Although right hemiplegia with facial weakness and dysarthria were noted, sensations to pinpricks were intact. MRI showed a hyperintense lesion in the posterior limb of the left internal capsule (IC), with decreased apparent diffusion coefficient values on diffusionweighted imaging (DWI), suggesting acute ischaemic stroke (AIS) (figure 1). In the coronal plane, the lesion appeared along the pyramidal tract, suggesting a pathology other than AIS. A laboratory examination revealed a decrease in the serum glucose level $(32 \mathrm{mg} / \mathrm{dL})$, whereon $40 \mathrm{~mL}$ of a $50 \%$ glucose solution was infused. The patient made a complete recovery without neurological deficits; follow-up MRI 2 days later revealed complete lesion resolution (figure 2). Based on the clinical course, hypoglycaemic hemiplegia was diagnosed. Hypoglycaemia may present with focal neurological signs such as hemiplegia. ${ }^{1}$ Moreover, hypoglycaemic hemiplegia can result in hyperintense lesions in the IC being noted on DWI, which are difficult to distinguish from AIS. ${ }^{2}$ However, although AIS lesions may be detected along the vascular territory, hypoglycaemic hemiplegia lesions might be present along the pyramidal tract, since the more compact neuronal tissue might be more vulnerable to hypoglycaemia. ${ }^{3}$ The coronal section in this case shows that the lesion is actually along the pyramidal tract and, to prevent a misdiagnosis, the coronal section is therefore very useful.

\section{Learning points}

Hypoglycaemic hemiplegia may mimic acute ischaemic stroke, not only clinically, but also radiologically.

- Hypoglycaemic hemiplegia should be considered in cases where diffusion-weighted imaging shows hyperintense lesions along the pyramidal tract in the coronal plane.

- A coronal section may be useful in distinguishing hypoglycaemic hemiplegia from acute ischaemic stroke.
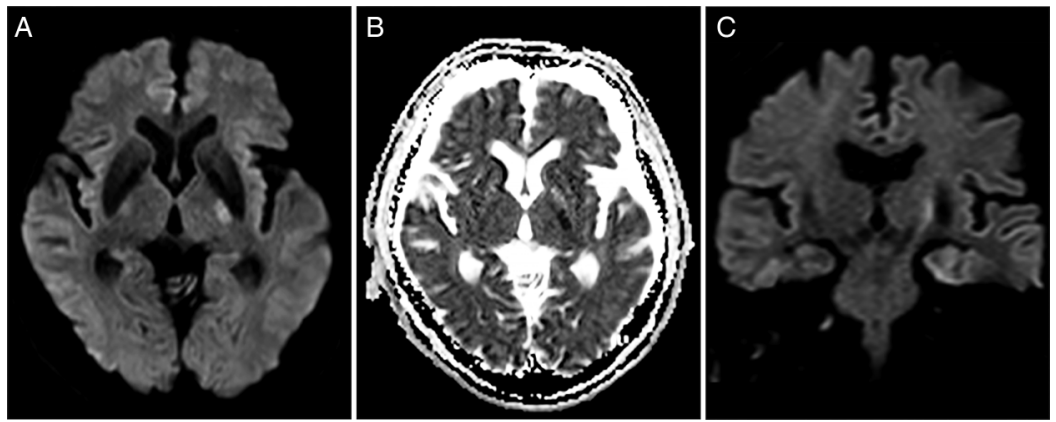

Figure 1 Axial DWI obtained on admission showing a hyperintense lesion on the posterior limb of the left internal capsule (A) with decreased $A D C$ values (B). DWI in the coronal plane showing a lesion along the pyramidal tract (C). $A D C$, apparent diffusion coefficient; DWI, diffusion-weighted imaging.
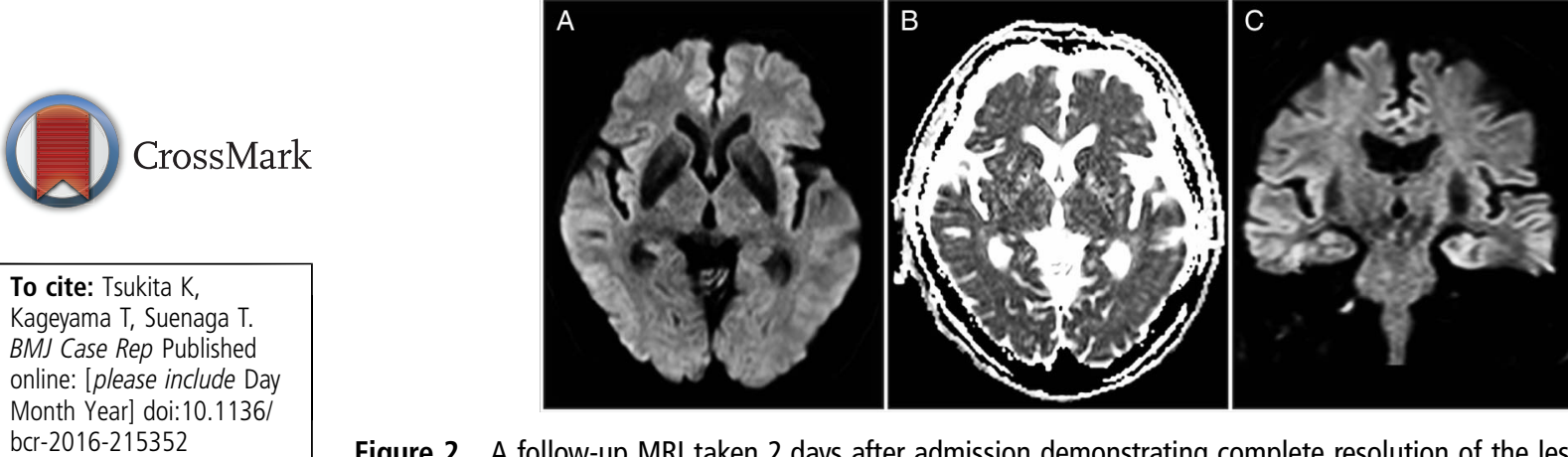

Figure 2 A follow-up MRI taken 2 days after admission demonstrating complete resolution of the lesion. 
Contributors KT was responsible for study concept and design, drafting and revising the manuscript, analysis and interpretation of data. TK was responsible for drafting the article and revising it critically for important intellectual content. TS was responsible for study concept and design, drafting and revising the manuscript, analysis and interpretation of data, and is guarantor of the study.

Competing interests None declared.

Patient consent Obtained.

Provenance and peer review Not commissioned; externally peer reviewed.

\section{REFERENCES}

1 Foster JW, Hart RG. Hypoglycemic hemiplegia: two cases and a clinical review. Stroke 1987;18:944-6.

2 Ohshita T, Imamura E, Nomura E, et al. Hypoglycemia with focal neurological signs as stroke mimic: clinical and neuroradiological characteristics. J Neurol Sci 2015;353:98-101.

3 Lee $\mathrm{SH}$, Kang CD, Kim SS, et al. Lateralization of hypoglycemic encephalopathy: evidence of a mechanism of selective vulnerability. J Clin Neurol 2010;6:104-8.

Copyright 2016 BMJ Publishing Group. All rights reserved. For permission to reuse any of this content visit http://group.bmj.com/group/rights-licensing/permissions.

BMJ Case Report Fellows may re-use this article for personal use and teaching without any further permission.

Become a Fellow of BMJ Case Reports today and you can:

- Submit as many cases as you like

- Enjoy fast sympathetic peer review and rapid publication of accepted articles

- Access all the published articles

- Re-use any of the published material for personal use and teaching without further permission

For information on Institutional Fellowships contact consortiasales@bmjgroup.com

Visit casereports.bmj.com for more articles like this and to become a Fellow 